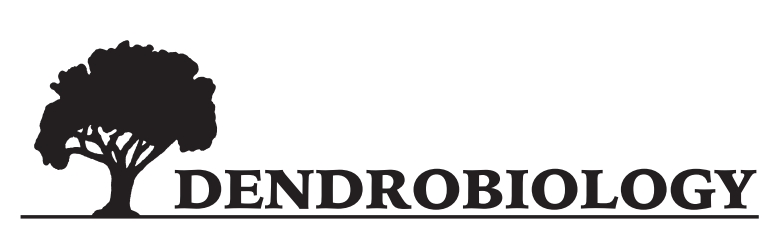

2017, vol. 77, 139-146

http://dx.doi.org/10.12657/denbio.077.011

\author{
Tamara Chadzinikolau, Monika Koztowska, Mirosław Mleczek
}

\title{
Induction of phytochelatins and flavonoids in cadmium polluted Berberis thunbergii
}

Received: 6 July 2016; Accepted: 20 February 2017

\begin{abstract}
Cadmium tolerance has been widely studied in various plant species. The study was undertaken to assess the response of Berberis thunbergii, commonly growing under urban conditions, to increasing concentrations of cadmium (1,4 and $16 \mathrm{mg}$ of $\mathrm{Cd} \mathrm{kg}^{-1}$ soil). Experiments were conducted from June to August in a greenhouse. Accumulation of cadmium ions in barberry leaves was observed, at a simultaneous occurrence of mechanisms reducing its harmful effects by an increased synthesis of phytochelatins (PCs). Generation of PCs - putative heavy metal chelators was related to the phytochelatin synthase activity (PCS) and the level of metal accumulation. Increased contents of anthocyanins and flavonols in cadmium polluted barberry, considering that it is a coloured-leaf plant seems important in aspect of their multifunctional role in plant-environment interactions. Besides the capacity to chelate heavy metals, flavonoids are antioxidants and efficiently scavenge free radicals. Moreover, the content of chloroplast pigments was determined, but the changes were non-significant.
\end{abstract}

Keywords: heavy metals, barberry, phytochelatin synthase, phytochelatins, flavonoids, chloroplast pigments

Addresses: T. Chadzinikolau, M. Kozłowska, Department of Plant Physiology, Poznań University of Life Sciences, Wołyńska 35, 60-637 Poznań, Poland, e-mail: tamaris@up.poznan.pl

M. Mleczek, Department of Chemistry, Poznań University of Life Sciences, Wojska Polskiego 75, 60-625

Poznań, Poland

\section{Introduction}

Heavy metals are important pollutants and their toxicity is a problem of increasing significance for ecological and environmental reasons (Nagajyoti et al., 2008). Cadmium with a long biological halflife can be easily taken up by plants, disrupting the control of the cells redox state and inducing a series of biochemical and physiological alterations (Rodríguez-Serrano et al., 2009; Tran \& Popova, 2013). Excess of cadmium causes growth retardation, inhibition of photosynthesis, induction and inhibition of enzymes, deterioration of water relations and generation of free radicals (Benavides et al., 2005).

Plants avoid the damaging effects of cadmium toxicity using defense strategies involving the metal ion binding to the cell walls and its immobilization, exclusion of the plasma membrane or chelation and subcellular compartmentation in the vacuoles (Anjum et al., 2015). In particular, chelation is the most widespread mechanism for the maintenance of low free metals and their detoxification (Clemens, 2001; Mejáre \& Bülow, 2001). Detoxification of Cd could be 
achieved by binding with amino acids, organic acids and phytochelatins. Cadmium stimulates production of phytochelatins through an activation of phytochelatin synthase (Yadaw, 2010). Due to their specific chemical structure, also flavonoids readily chelate metal ions and create complex compounds (Lachman et al., 2005). Flavonoids are secondary plant metabolites with a vast array of possible protective functions, including antioxidant activity (Keilig \& Ludwig-Müller, 2009).

Leaf pigment contents provide valuable information concerning the physiological status of plants and may indicate the occurrence of metal intoxication (Dobroviczká et al., 2013). Chloroplast pigments give an indirect estimation of the nutritional status of plants since much of leaf nitrogen is incorporated into the chlorophyll (Moran et al., 2000). Moreover, chlorophyll content is closely related to plant stress and senescence. In turn, carotenoids plays a structural role in the organization of photosynthetic membranes, participation in light harvesting, transfer of energy, interception of deleterious organic radicals and free oxygen and quenching. Information on both pigment contents may be used as an indicator of metal toxicity (Benavides et al., 2005).

The aim of the study was to evaluate whether barberry shrubs trigger defense strategies against cadmium pollution. The effect of $\mathrm{Cd}\left(\mathrm{NO}_{3}\right)_{2}$ on phytochelatin synthesis, flavonoid accumulation and chloroplast pigments in barberry leaves was investigated. This research complements previous studies on Berberis thunbergii growing in the natural environment close to transport routes (Chadzinikolau et al., 2010; Pietrowska-Borek et al., 2010). Barberry is a decorative plant. Thanks to its salinity resistance, frost and drought tolerance, it is frequently used in urban landscape architecture. Therefore, it is important to gain insight into the mechanism of tolerance to environmental pollution.

\section{Material and methods}

\section{Plant material and experimental design}

Shrubs of barberry (Berberis thunbergii DC.) of 'Red Chief' cv. were collected from a nursery plantation where they were growing in 5-liter pots. At the end of April shrubs were replanted to 10 liter pots (garden soil, peat substrate and de-acidified peat at a ratio of 1:2:2; $\mathrm{pH} 6,4)$. Experiments were conducted from June to August in a manual greenhouse. Four cadmium treatments with $\mathrm{Cd}\left(\mathrm{NO}_{3}\right)_{2}$ were conducted by $0,1,4$ and $16 \mathrm{mg} \mathrm{Cd} \mathrm{kg}^{-1}$ of soil, respectively. The plants were polluted in three week intervals, i.e. June 4, June 24 and July 14, each time with described doses, and watered every 2-3 days with $500 \mathrm{~cm}^{3}$. Each combination was in four replications (4 plants).

Leaves were harvested on June 3 (time 0), June 23 (3 weeks), July 13 (6 weeks) and August 2 (9 weeks after Cd treatment), respectively. For cadmium measurement plant materials and soil were harvested at the beginning and the end of the experiment. In order to determine the contents of phytochelatins (PCs), the activity of phytochelatin synthase (PCS) and flavonoids leaves were surface-washed in distilled water, and $0.5 \mathrm{~g}$ weighted samples were frozen in liquid nitrogen and stored at $-18^{\circ} \mathrm{C}$. The contents of chlorophyll and carotenoids were determined in the fresh material. Analyses for each parameter were made in four analytical replicates.

\section{Thiols content and phytochelatin synthase activity}

PCs were isolated and separated according to Stroiński \& Zielezińska (1997), using the method presented by Tukendorf \& Rauser (1990). Frozen leaves $(0.5 \mathrm{~g})$ were homogenized with an Art-Miccra homogenizer in $2 \mathrm{ml}$ of $0.5 \mathrm{mmol} \mathrm{dm}{ }^{-3} \mathrm{HCl}$. PCs were estimated using reverse-phase HPLC (Varian Pro Star) with post-column derivatization using Ellman's reagent and measured at A405 between 22-28 minutes of elution from the column. The amount of PCs was calculated in reference to the GSH standard.

PCS activity was determined according to Grill et al. (1989). Frozen material (1.5 g) was homogenized in $6 \mathrm{ml}$ of $100 \mathrm{mmol} \mathrm{dm}^{-3}$ Tris-HCl extraction buffer (pH 8.0) containing $10 \mathrm{mmol} \mathrm{dm}{ }^{-3}$ mercaptoethanol, $2.5(\mathrm{w} / \mathrm{v})$ polyvinylpolypirolidone, $1 \mathrm{mmol} \mathrm{dm}^{-3}$ $\mathrm{K}_{2}$ EDTA and 5\% (v/v) glycerol. The homogenate was centrifuged twice for $30 \mathrm{~min}$ at $30000 \mathrm{~g}$ at $4^{\circ} \mathrm{C}$. The supernatant was collected as crude extract and subjected to ammonium sulfate precipitation (40 and $70 \%$ saturation). Pellets were dissolved in $1 \mathrm{ml}$ of $50 \mathrm{mmol} \mathrm{dm}^{-3}$ Tris- $\mathrm{HCl}$ buffer ( $\mathrm{pH} 8.0$ ) containing $25 \mathrm{mmol} \mathrm{dm}^{-3} \mathrm{KCl}, 10 \mathrm{mmol} \mathrm{dm}^{-3}$ mercaptoethanol, $0.5 \mathrm{mmol} \mathrm{dm}^{-3} \mathrm{~K}_{2}$ EDTA and $20 \mathrm{mmol} \mathrm{dm}^{-3} \mathrm{MgCl}_{2}$ and they were dialyzed overnight. Insoluble material was removed by centrifugation and the supernatant was used for PC-synthase determination. The incubation mixture contained in the final volume of 1.2 $\mathrm{ml}$ : extract (0.7-1.5 $\mathrm{mg}$ protein), $50 \mathrm{mmol} \mathrm{\textrm {dm } ^ { - 3 }}$ TrisHCI (pH 8.0), $1 \mathrm{mmol} \mathrm{dm}^{-3} \mathrm{MgCl}_{2}$ and $45 \mathrm{mmol} \mathrm{dm}^{-3}$ $\mathrm{KC} 1,10 \mathrm{mmol} \mathrm{dm}^{-3}$ mercaptoethanol, $0.2 \mathrm{mmol} \mathrm{dm}^{-3}$ gluthatione and $2 \mathrm{mmol} \mathrm{dm}{ }^{-3} \mathrm{CdCl}_{2}$. After incubation for $60 \mathrm{~min}$ at $35^{\circ} \mathrm{C}, 0.1 \mathrm{ml} 0.6 \mathrm{mmol} \mathrm{dm}^{-3} \mathrm{NaOH}$ containing $1 \mathrm{mg} \mathrm{NaBH} \mathrm{N}_{4}$ was added. The mixture was neutralized by $0.15 \mathrm{ml} 5 \mathrm{~N} \mathrm{HC1}$. As a product of enzyme reaction, the level of phytochelatins was estimated as described above. Total protein content was measured according to Bradford (1976). 


\section{Vacuolar pigments}

Flavonols and anthocyanins were determined as described by Pietrowska-Borek et al. (2010). For flavonols leaf samples ( $0.5 \mathrm{~g}$ ) were cut and homogenized with $5 \mathrm{ml}$ of a mixture of methanol, $\mathrm{HCl}$ and distilled $\mathrm{H}_{2} \mathrm{O}(90: 1: 1, \mathrm{v} / \mathrm{v} / \mathrm{v})$. Homogenates were stirred and heated $\left(60^{\circ} \mathrm{C}\right)$ for $10 \mathrm{~min}$, cooled at room temperature for $15 \mathrm{~min}$ and centrifuged at 23000 $\mathrm{g}$ for $30 \mathrm{~min}$. Anthocyanins were measured according to Arakawa (1991). Plant material (0.5 g) was homogenized with $0.5 \mathrm{~N} \mathrm{HCl}$, and centrifuged at 18 $000 \mathrm{~g}$ for $30 \mathrm{~min}$. Contents of both pigments were determined by measuring absorbance of the supernatant with a UV/visible spectrophotometer (Jasco V-530 UV-VIS Spectrophotometer) at $254 \mathrm{~nm}$ for flavonols and at $530 \mathrm{~nm}$ for anthocyanins. Flavonols level was calculated using quercetin (Stefova et al., 2001), while that of anthocyanins were determined using cyanine chloride and expressed in $\mu \mathrm{g} \mathrm{g}^{-1}$ of fresh weight $(\mathrm{FW})$.

\section{Chloroplast pigments}

Chlorophyll and carotenoids were extracted using the Hiscox \& Israelstam (1979) procedure. Leaves without petioles were cut and flooded with $5 \mathrm{ml}$ dimethyl sulfoxide (DMSO) in glass tubes, and incubated at $70^{\circ} \mathrm{C}$ for $30 \mathrm{~min}$ until all of the visible green pigmentation disappeared. After cooling the samples were 5-fold diluted with DMSO and measured at 480, 649 and $655 \mathrm{~nm}$ with a UV/visible spectrophotometer (Jasco V-530) to quantify the chlorophyll and carotenoid concentrations based on the equations reported by Wellburn (1994). Results are expressed in $\mathrm{mg} \mathrm{g}^{-1}$ of fresh weight (FW).

\section{Cadmium determination}

Soil samples were analyzed according to the PNR-04031:1997 and PN-ISO 11464:1999 standards. Collected samples were dried on Petri dishes within 48 hours in an electric oven (SLW 53 STD, PolEko, Wodzisław Śląski, Poland) and then ground in an agate mortar to obtain the powder fraction. Thus prepared samples $(0.5000 \pm 0.0001 \mathrm{~g}$ each $)$ were transported to glass bulbs with $28 \mathrm{ml}$ of aqua regia $\left(21 \mathrm{ml}\right.$ of $36 \% \mathrm{HCl}$ and $7 \mathrm{ml}$ of $65 \% \mathrm{HNO}_{3}$ ) to 24 hours. After that samples were digested according to the PN-ISO 11466:2002 standard within 6 hours and temperature $107^{\circ} \mathrm{C}$. Materials were filtered using 45-mm filters (Qualitative Filter Papers Whatman, Grade 595: 4-7 $\mu \mathrm{m}$ ) and diluted to a final volume of $50 \mathrm{ml}$.

Leaves collected for analyses were washed using deionized ultrapure water to remove metal ions adsorbed at their surface and dried in an electric oven within $96 \mathrm{~h}$ at $105 \pm 5^{\circ} \mathrm{C}$. Samples were ground in a laboratory cutting mill (200 SM by Retsch $\mathrm{GmbH}$, Haan, Germany) to obtain a powder fraction. Dry samples $(0.500 \pm 0.001 \mathrm{~g})$ were digested in the Mars 5 Xpress closed microwave system (CEM, Matthews, USA) using $8 \mathrm{ml} 65 \% \mathrm{HNO}_{3}$ in closed tubes $(55 \mathrm{ml})$. The solutions were filtered using paper filters, supernatants were diluted to a final volume of $50 \mathrm{ml}$. Each of the samples was processed in 3 replicates.

Cadmium contents in the soil and plant samples were determined by flame atomic absorption spectrometry using a graphite furnace atomic absorption spectrometer (GFAAS) SpectrAA 280Z (Agilent Technologies, Mulgrave, Victoria, Australia). The following determination conditions were applied: $\mathrm{Cd}$ $228.8 \mathrm{~nm}$, slit $0.5 \mathrm{~nm}$, background correction with a deuterium lamp. The detection limit for $\mathrm{Cd}$ was 0.01 $\mathrm{mg} \mathrm{kg}^{-1}$ (for dry samples). Analysis of $\mathrm{Cd}$ and verification of result quality were performed according to the procedures described by Niedzielski et al. (2015).

Efficiency of cadmium phytoextraction was characterized by the BAF value (bioaccumulation factor), which was calculated as the ratio of cadmium concentration in leaves to its amount in the soil. Depending on BAF values, accumulation efficiency was estimated using one of the four following groups: [1 (intensive), 1-0.1 (medium), 0.1-0.01 (weak) and 0.01-0.001 (no accumulation)] (Kabata-Pendias \& Pendias, 1999).

\section{Statistical analysis}

Results were subjected to the statistical analysis of variance ANOVA and Tukey's HSD multiple range test, using the Statistica 12.0 software. The correlation between the level of physiological parameters and leaf cadmium concentration was tested based on the correlation coefficient. Moreover, linear regression was determined for the relationship between phytochelatin synthase (PCS) activity and the content of phytochelatins (PCs).

\section{Results}

The effect of Cd treatment on cadmium accumulation in barberry leaves in relation to its content in the soil were assessed and the obtained results are given in Fig. 1. Cadmium content in the soil exceeded the exposure limits (4-5 $\mathrm{mg} \mathrm{kg}^{-1}$ ) and even critical values (5-10 $\mathrm{mg} \mathrm{kg}^{-1}$ ), according to the status of soil pollution proposed by Gambuś \& Gorlach (2001). The accumulation efficiency in barberry leaves does not indicate the phytoextraction potential of this plant with BAF values of $0.1-1$ (Table 1 ).

Cadmium had a significant effect on PC formation and influenced PCS activity (Fig. 2). Both were 


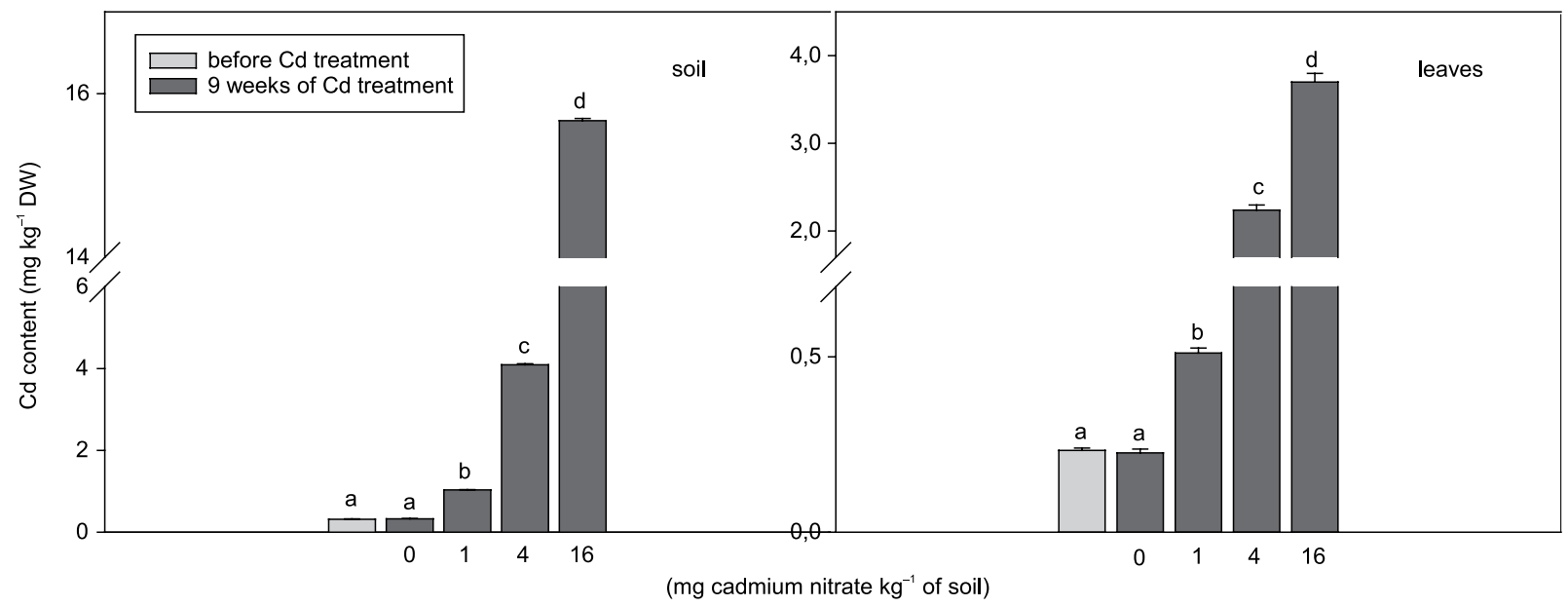

Fig. 1. Cadmium content in soil and leaves of Berberis thunbergii after the cadmium nitrate treatment. Means with the same letter are not significantly different $(\mathrm{P}<0.05$, ANOVA followed by Tukey HSD test)

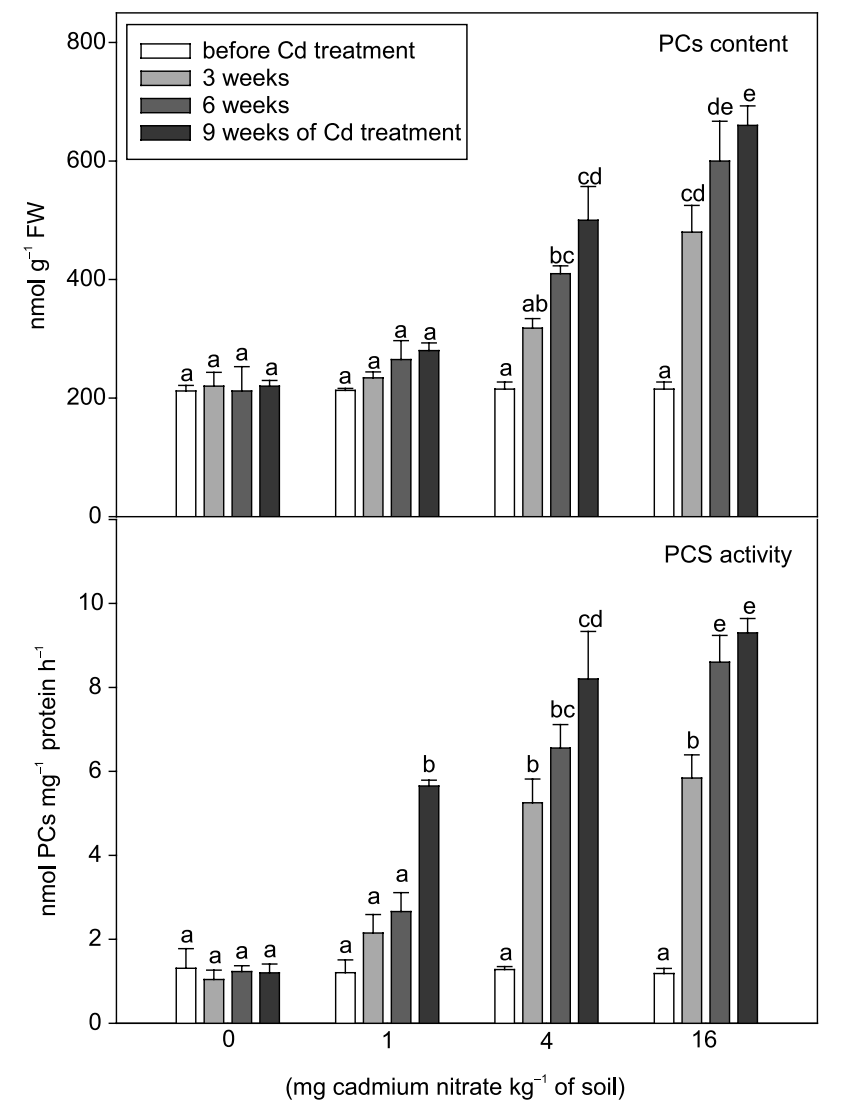

Fig. 2. Phytochelatins (PCs) content and phytochelatin synthase (PCS) activity in leaves of Berberis thunbergii after the cadmium nitrate treatment. Means with the same letter are not significantly different $(\mathrm{P}<0.05$, ANOVA followed by Tukey HSD test)
Table 1. Bioaccumulation factor (BAF) values for particular cadmium doses

\begin{tabular}{cc}
\hline $\begin{array}{c}\text { Cadmium concentration } \\
\left(\mathrm{mg} \mathrm{kg}^{-1} \text { of soil) }\right.\end{array}$ & $\begin{array}{c}\text { BAF } \\
\text { (bioaccumulation factor) }\end{array}$ \\
\hline 1 & 0,49 \\
4 & 0,55 \\
16 & 0,23 \\
\hline
\end{tabular}

dependent on cadmium contamination and the period of cadmium exposure. In plants exposed to 4 and $16 \mathrm{mg} \mathrm{Cd} \mathrm{kg}^{-1}$ of soil the content of PCs was two-fold greater than that of control plants. The activity of

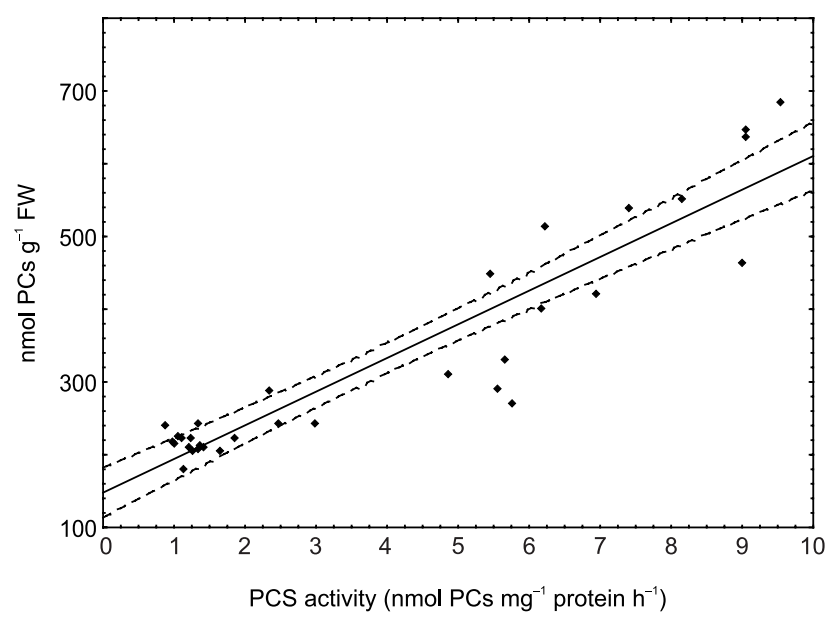

Fig. 3. The relationship between phytochelatins accumulation and phytochelatin synthase activity in leaves of Berberis thunbergii

Table 2. Correlation coefficient between leaf cadmium concentration and physiological parameters

\begin{tabular}{ccccccc}
\hline Leaf Cd concentration & PCs & PCS activity & anthocyanins & flavonols & chl $a+b$ & carotenoids \\
\hline control & 0.45 & 0.56 & $0.62^{*}$ & 0.10 & 0.07 & -0.02 \\
$1 \mathrm{mg}$ & $0.75^{*}$ & $0.96^{* * *}$ & $0.82^{* *}$ & $0.81^{* *}$ & 0.40 & 0.00 \\
$4 \mathrm{mg}$ & $0.95^{* * *}$ & $0.96^{* * *}$ & $0.88^{* * *}$ & $0.82^{* * *}$ & 0.10 & -0.55 \\
$16 \mathrm{mg}$ & $0.96^{* * *}$ & $0.97^{* * *}$ & $0.89^{* *}$ & $0.86^{* *}$ & 0.06 & $-0.77^{* *}$ \\
\hline
\end{tabular}

***significant at the level $0.001,{ }^{* *}$ significant at the level $0.01,{ }^{*}$ significant at the level 0.05 . 

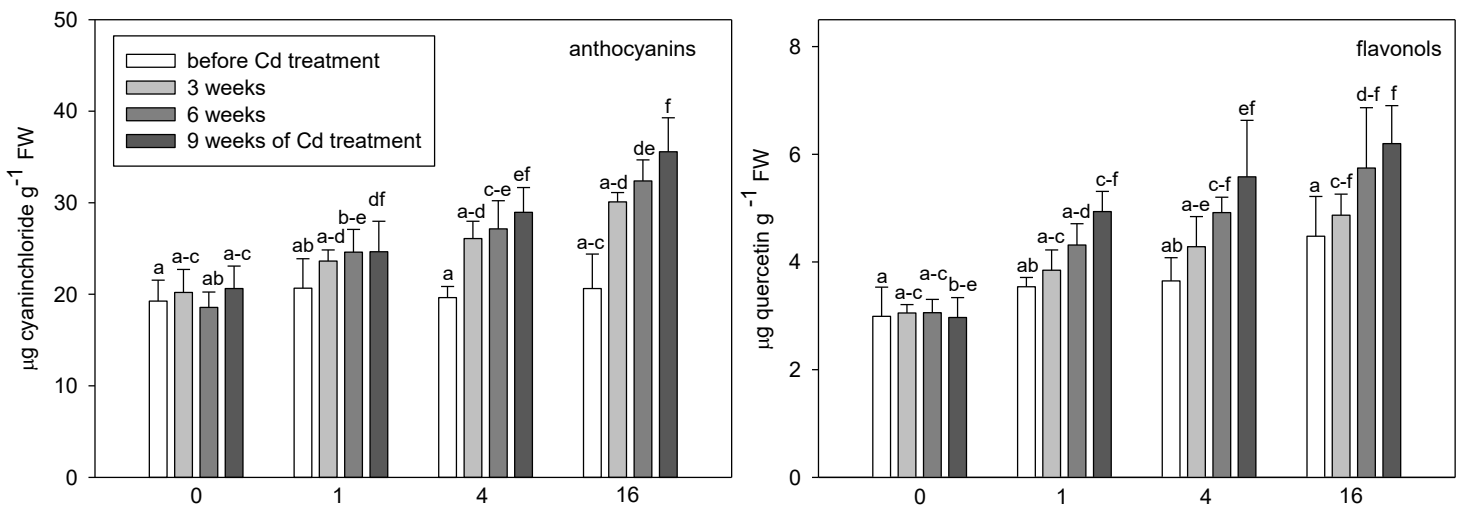

(mg cadmium nitrate $\mathrm{kg}^{-1}$ of soil)

Fig. 4. Vacuolar pigments content in leaves of Berberis thunbergii after the cadmium nitrate treatment. Means with the same letter are not significantly different $(\mathrm{P}<0.05$, ANOVA followed by Tukey HSD test)

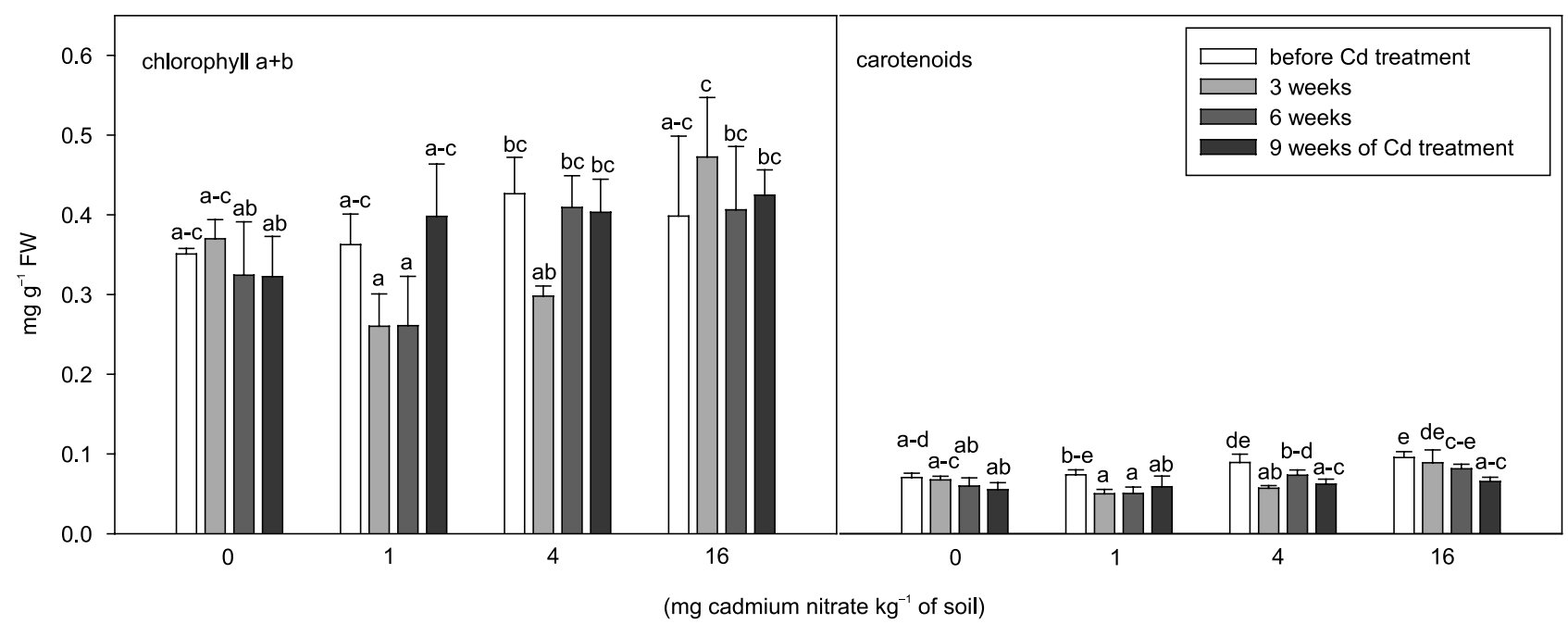

Fig. 5. Chloroplast pigments content in leaves of Berberis thunbergii after the cadmium nitrate treatment. Means with the same letter are not significantly different $(\mathrm{P}<0.05$, ANOVA followed by Tukey HSD test)

Table 3. Summary of ANOVA results for physiological parameters by cadmium concentration and term of material collection (NS - non significant)

\begin{tabular}{|c|c|c|c|c|c|c|}
\hline \multirow{2}{*}{ Source of variation } & \multicolumn{3}{|c|}{ PCs } & \multicolumn{3}{|c|}{ PCS activity } \\
\hline & d.f. & $\mathrm{F}$ & $P$ & d.f. & $\mathrm{F}$ & $P$ \\
\hline $\mathrm{Cd}(\mathrm{C})$ & 3 & 127.91 & $<0.0001$ & 3 & 186.56 & $<0.0001$ \\
\hline Term (T) & 3 & 63.64 & $<0.0001$ & 3 & 150.35 & $<0.0001$ \\
\hline $\mathrm{C} \times \mathrm{T}$ & 9 & 17.20 & $<0.0001$ & 9 & 26.82 & $<0.0001$ \\
\hline Error & 16 & & & 16 & & \\
\hline \multirow{2}{*}{ Source of variation } & \multicolumn{3}{|c|}{ anthocyaninis } & \multicolumn{3}{|c|}{ flavonols } \\
\hline & d.f. & $\mathrm{F}$ & $P$ & d.f. & $\mathrm{F}$ & $P$ \\
\hline $\mathrm{Cd}(\mathrm{C})$ & 3 & 24.42 & $<0.0001$ & 3 & 15.25 & $<0.0001$ \\
\hline Term $(\mathrm{T})$ & 3 & 42.35 & $<0.0001$ & 3 & 46.72 & $<0.0001$ \\
\hline $\mathrm{C} \times \mathrm{T}$ & 9 & 4.46 & 0.0003 & 9 & 1.93 & NS \\
\hline Error & 48 & & & 48 & & \\
\hline \multirow{2}{*}{ Source of variation } & \multicolumn{3}{|c|}{$\operatorname{chl} a+b$} & \multicolumn{3}{|c|}{ carotenoids } \\
\hline & d.f. & $\mathrm{F}$ & $P$ & d.f. & $\mathrm{F}$ & $P$ \\
\hline $\mathrm{Cd}(\mathrm{C})$ & 3 & 11.69 & $<0.0001$ & 3 & 25.70 & $<0.0001$ \\
\hline Term $(\mathrm{T})$ & 3 & 2.28 & NS & 3 & 19.47 & $<0.0001$ \\
\hline $\mathrm{C} \times \mathrm{T}$ & 9 & 3.74 & 0.0013 & 9 & 3.63 & 0.0017 \\
\hline Error & 48 & & & 47 & & \\
\hline
\end{tabular}


PCS increased even at the lowest Cd treatment (1 mg $\mathrm{Cd} \mathrm{kg}^{-1}$ of soil), whereas under 4 and $16 \mathrm{mg}$ doses it increased strikingly, i.e. almost 7 - and 8-fold, respectively, after 9 weeks of $\mathrm{Cd}$ exposure. The correlation between PCS activity and PC levels revealed a positive and statistically significant relationship (Fig. 3).

Changes in anthocyanin and flavonol production in polluted barberry leaves are shown in Fig. 4. Under $\mathrm{Cd}$ stress the content of both flavonoids increased, with the accumulation being dependent on cadmium contamination levels and the period of cadmium exposure. All cadmium treatments were found to have a significant effect on the analysed parameters (Tables 2 and 3 ).

Variations in chlorophyll and carotenoid levels of cadmium-treated barberry leaves (Fig. 5) were non-significant under the applied experimental conditions, except for a decrease of carotenoid contents under the highest $\mathrm{Cd}$ concentration (Tables 2 and 3 ).

\section{Discussion}

Accumulation of lead, zinc and cadmium, as well as the activation of a defense response mechanism were found in barberry response to urban pollutants (Chadzinikolau et al., 2010; Pietrowska-Borek et al., 2010). Plants were characterised by an increased synthesis of phytochelatins as putative heavy metals chelators, and induction of phytochelatin synthase activity as a key enzyme involved in heavy metal detoxification. Moreover, the activation of the phenylpropanoid pathway was observed, including an increased 4-coumarate-CoA ligase activity and the accumulation of anthocyanins and flavonols.

Referring to the above-mentioned environmental findings, model studies involving cadmium application to the soil were performed. In general, cadmium causes many physiological and biochemical changes connected with the tolerance mechanism or resulting in metabolic and growth disturbance. The capacity to accumulate $\mathrm{Cd}$ was observed to vary in plant species, including woody plants (Capuana, 2011; Vassilev et al., 2002). Cd is readily immobilised in roots, but also translocated to the aerial part (Unterbrunner et al., 2007).

Despite the fact that barberry plants accumulate cadmium, no visible symptoms of Cd toxicity were observed. Usually cadmium phytotoxicity is manifested by growth inhibition and various types of root system deformations, resulting in the wilting of aboveground parts and leaf chlorosis (Benavides et al., 2005). However, even the highest Cd concentration in the rhizosphere proved to be tolerable for barberry. Moreover, the bioaccumulation factor (BAF, defined as the total concentration in leaves with respect to concentration in soil, both in $\mathrm{mg} \mathrm{kg}^{-1}$ ) was calculated, which confirmed that barberry may be classified as a tolerant plant species. When compared to $\mathrm{Cd}$ accumulation e.g. in Pinus sylvestris seedlings (Modirroosta et al., 2014), the level of Cd in barberry leaves was 10-fold higher at similar doses of $\mathrm{Cd}$ application.

Plants have developed a complex network of highly effective mechanisms that serve to control the uptake, accumulation and detoxification of metals (Manara, 2012). A major strategy for detoxification of non-essential elements consists in the synthesis of specific low-molecular-weight chelators to avoid their binding to physiologically important proteins and to facilitate their transport into the vacuoles. Phytochelatins (PCs) are common chelators, forming high-molecular-weight (HMW) complexes in the vacuoles. Their formation is catalysed by the cytosolic PC synthase (PCS), post-translationally activated by heavy metals (Cobbett \& Goldsbrough, 2002). This strategy includes the plant defense against cadmium (Tran \& Popova, 2013; Vassilev et al., 2002) and it was found in barberry. It needs to be stressed that the involvement of phytochelatins in heavy metal tolerance of woody plants is poorly documented (Dominguez et al., 2011; Gu et al., 2007; Modirroosta et al., 2014). However, further studies would be required to verify whether this species has characteristics of a hyperaccumulator and may be a promising option for phytoremediation. There is much evidence that some types of trees can survive under severe adverse conditions, e.g. Salix, Populus, etc. (Almeida et al., 2007; Unterbrunner et al., 2007; Capuana, 2011; Hayakawa et al., 2011)

Apart from phytochelatins, other metabolites may be involved in tolerance mechanisms to heavy metals. Flavonoids exhibit a broad range of biological activity, connected to their antioxidant activity, free radicals scavenging and metal ion chelation (Korkina, 2007; Landi et al., 2015; Michalak, 2006). In particular, an important role of anthocyanins in protection against copper ions has been demonstrated (Posmyk et al., 2009). At present coloured-leaf woody plants, similar to the barberry cv. 'Red Chief', are considered to be of particular interest. These plants not only remediate the contaminated environment, but also bring landscape effects. Our results showed that the $\mathrm{Cd}$ treatments induced flavonoid accumulation, including anthocyanins. These results are in agreement with findings presented by Zhang et al. (2014), who demonstrated that $\mathrm{Cd}$ induced anthocyanin accumulation in coloured poplar.

Common symptoms of $\mathrm{Cd}$ phytotoxicity include leaf chlorosis or sensitivity of photosynthetic pigments (MacFarlane \& Burchett, 2001). Cadmium could alter chlorophyll biosynthesis and cause chlorophyll destruction (Nicolić et al., 2008). However, the amounts of Chl $a$ and $b$ did not change in the 
$\mathrm{Cd}$ treated barberry. These results suggest that the level of cadmium was not toxic for the chlorophyll metabolism. The situation was slightly different for carotenoid contents, as their level decreased. While it is difficult to explain, it suggests a greater sensitivity of metabolic processes in the case of these photopigments.

In our experiments cadmium was treated as a nitrate salt, so nitrate ions were supplied together with Cd pollution. Nitrogen as an important growth factor and a compound responsible for chlorophyll synthesis can modulate the level of secondary metabolites (Ibrahim et al., 2011). However, the amount of supplied nitrate at the highest Cd dose was below $10 \mathrm{mg}$ $\mathrm{kg}^{-1}$ of soil, therefore it was rather negligible.

In conclusion, phytochelatins and flavonoids may play a significant role in barberry Cd tolerance, leading to the accumulation of cadmium chelates in the vacuoles and probably reducing oxidative stress. Considering the multifunctional role of flavonoids, these pigments seem to be important in the environmental response of coloured-leaf barberry

\section{References}

Almeida A-AF, Valle RR, Mielke MS \& Gomes FP (2007) Tolerance and prospection of phytoremediator woody species of $\mathrm{Cd}, \mathrm{Pb}, \mathrm{Cu}$ and $\mathrm{Cr}$. Brazilian Journal of Plant Physiology 19: 83-98.

Anjum NA, Hasanuzzaman M, Hossain MA, Thangavel P, Roychoudhury A, Gill SS, Rodrigo MAM, Adam V, Fujita M, Kizek R, Duarte AC, Pereira E \& Ahmad I (2015) Jacks of metal/metalloid chelation trade in plants - an overview. Frontiers in Plant Science 6: 192.

Arakawa O (1991) Effect of temperature on anthocyanin accumulation in apple fruit as affected by cultivar, stage of fruit ripening and bagging. The Journal of Horticultural Science and Biotechnology 66: 763-768.

Benavides MP, Gallego SM \& Tomaro ML (2005) Cadmium toxicity in plants. Brazilian Journal of Plant Physiology 17: 21-34.

Bradford MM (1976) A rapid and sensitive method for the quantitation of microgram quantities of protein utilizing the principle of protein-dye binding. Analytical Biochemistry 72: 248-254.

Capuana M (2011) Heavy metals and woody plants - biotechnologies for phytoremediation. iForest Biogeosciences and Forestry 4: 7-15.

Chadzinikolau T, Kozłowska M \& Mleczek M (2010) Response of Berberis thunbergii to heavy metals under urban pollution. Dendrobiology 64: 65-72.

Clemens S (2001) Molecular mechanisms of plant metal tolerance and homeostasis. Planta 212: 475-486.
Cobbett C \& Goldsbrough P (2002) Phytochelatins and metallothioneins: roles in heavy metal detoxification and homeostasis. Annual Review of Plant Biology 53: 159-182.

Dobroviczká T, Piršelová B, Mészáros P, Blehová A, Iibantová J, Moravčíková J \& Matušíková I (2013) Effects of cadmium and arsenic ions on content of photosynthetic pigments in the leaves of Glycine $\max$ (L.) merrill. Pakistan Journal of Botany 45: 105-110.

Dominguez MT, Maranón T, Mirillo JM \& Rodondo-Gómez S (2011) Response of Holm oak (Quercus ilexsubsp. Ballota) and mastic shrub (Pistacia lentiscus L.) seedlings to high concentration of $\mathrm{Cd}$ and T1 in rhizosphere. Chemosphere 84: 11661174.

Gambuś F \& Gorlach E (2001) Ocena i stan zanieczyszczenia gleb w Polsce. Aura 7: 10-11.

Grill E, Löffler S, Winnacker EL \& Zenk MH (1989) Phytochelatins, the heavy-metal binding peptides of plants, are synthesized from glutathione by specific gamma-glutamylcysteine dipeptidyl transpeptidase (phytochelatin synthase). The Proceedings of the National Academy Sciences USA 86: 6838-6942.

Gu J, Qi L, Jiang W \& Liu D (2007) Cadmium accumulation and its effects on growth and gas exchange in four Populus cultivars. Acta Biologica Cracoviensia Series Botanica 49: 7-14.

Hiscox JD \& Israelstam GF (1979) A method for the extraction of chlorophyll from leaf tissue without maceration. Canadian Journal of Botany 57: 1332-1334.

Hayakawa N, Tomioka R \& Takenaka C (2011) Effects of calcium on cadmium uptake and transport in the tree species Gamblea innovans. Soil Science and Plant Nutrition 57: 691-695.

Ibrahim MH, Jaafar HZE, Rahmat A \& Rahman ZA (2011) Effects of nitrogen fertilization on synthesis of primary and secondary metabolites in three varieties of kacip fatimah (Labisia pumila Blume). International Journal of Molecular Sciences 12: 5238-5254.

Kabata-Pendias A \& Pendias H (1999) Biogeochemia pierwiastków śladowych. 2nd ed. PWN, Warsaw, Poland.

Keilig K \& Ludwig-Müller J (2009) Effect of flavonoids on heavy metal tolerance in Arabidopsis thaliana seedlings. Botanical Studies 50: 311-318.

Korkina LG (2007) Phenylpropanoids as naturally occurring antioxidants: from plant defense to human health. Cellular and Molecular Biology 53: 15-25.

Lachman J, Dudjak J, Miholová D, Kolihová D \& Pivec V (2005) Effect of cadmium on flavonoid content in young barley (Hordeum sativum L.) plants. Plant Soil and Environment 51: 513-516. 
Landi M, Tattini M \& Gould KS (2015) Multiple functional roles of anthocyanins in plant-environment interactions. Environmental and Experimental Botany 119: 4-17.

Manara A (2012) Plant responses to heavy metal toxicity: Plants and heavy metals (ed. by A Furini) Netherlands: SpringerBriefs in Molecular Science, pp. 27-53.

MacFarlane GR \& Burchett MD (2001) Photosynthetic pigments and peroxidase activity as indicators of heavy metal stress in the grey mangrove, Avicennia marina (Forsk.) Vierh. Marine Pollution Bulletin 42: 233-240.

Mejáre M \& Bülow L (2001) Metal-binding proteins and peptides in bioremediation and phytoremediation of heavy metals. Trends in Biotechnology 19: 67-73.

Michalak A (2006) Phenolic compounds and their antioxidant activity in plants growing under heavy metal stress. Polish Journal of Environmental Studies 15: 523-530.

Modirroosta S, Ardalan MM \& Bayramzadeh V (2014) Impact of soil cadmium contamination on accumulation of cadmium and proline content of Pinus sylvestris L. seedling. Agriculture Science Developments 3: 167-172.

Moran JA, Mitchell AK, Goodmanson G \& Stockburger KA (2000) Differentiation among effects of nitrogen fertilization treatments on conifer seedlings by foliar reflectance: a comparison of methods. Tree Physiology 20: 1113-1120.

Nagajyoti PC, Lee KD \& Sreekanth TVM (2008) Heavy metals, occurrence and toxicity for plants: a review. Environmental Chemisty Letters 8: 199_ 216.

Nicolić N, Kojić D, Pilipović A, Pajević S, Krstić B, Borišev M \& Orlović S (2008) Responses of hybrid poplar to cadmium stress: photosynthetic characteristics, cadmium and proline accumulation, and antioxidant enzyme activity. Acta Biologica Cracoviensia Series Botanica 50: 95-103.

Niedzielski P, Kozak L, Wachelka M, Jakubowski K \& Wybieralska J (2015) The microwave induced plasma with optical emission spectrometry (MIPOES) in 23 elements determination in geological samples. Talanta 132: 591-599.

Pietrowska-Borek M, Chadzinikolau T \& Kozłowska M (2010) Effect of urban pollution on 4-coumarate:CoA ligase and flavonoid accumulation in Berberis thunbergii. Dendrobiology 64: 79-86.

PN-R-04031 (1997) The chemical - agricultural analysis of the soil. Sampling.

PN-ISO 11464 (1999) The quality of the soil. Preliminary samples preparation for physico-chemical studies.
PN-ISO 11466 (2002) The quality of the soil. Extraction of trace soluble elements in aqua regia.

Posmyk MM, Kontek R \& Janas KM (2009) Antioxidant enzymes activity and phenolic compounds content in red cabbage seedlings exposed to copper stress. Ecotoxicology and Environmental Safety 72: 596-602.

Rodríguez-Serrano M, Romero-Puertas MC, Pazmiño DM, Testillano PS, Risueño MC, Del Río LA \& Sandalio LM (2009) Cellular response of pea plants to cadmium toxicity: cross talk between reactive oxygen species, nitric oxide, and calcium. Plant Physiology 150: 229-243.

Stefova M, Kulevanova S \& Stafilov T (2001) Assay of flavonols and quantification of quercetin in medicinal plants by HPLC with UV-diode array detection. Journal of Liquid Chromatography and Related Technologies 24: 2283-2292.

Stroiński A \& Zielezińska M (1997) Cadmium effect on hydrogen peroxide, gluthatione and phytochelatins levels in potato tuber. Acta Physiologiae Plantarum 19: 127-135.

Tran TA \& Popova LP (2013) Functions and toxicity of cadmium in plants: recent advances and future prospects. Turkish Journal of Botany 37: 1-13.

Tukendorf A \& Rauser WE (1990) Changes in glutathione and phytochelatins in roots of maize seedlings exposed to cadmium. Plant Science 70: 155-166.

Unterbrunner R, Puschenreiter $\mathrm{M}$, Sommer $\mathrm{P}$, Wieshammer G, Tlustoš P, Zupan M \& Wenzel WW (2007) Heavy metal accumulation in trees growing on contaminated sites in Central Europe. Environmental Pollution 148: 107-114.

Vassilev A, Vangronsveld J \& Yordanov I (2002) Cadmium phytoextraction: present state, biological backgrounds and research needs. Bulgarian Journal of Plant Physiology 28: 68-95.

Wellburn AR (1994) The spectral determination of chlorophylls a and b, as well as total carotenoids, using various solvents with spectrophotometers of different resolution. Journal of Plant Physiology 144: 307-313.

Yadaw SK (2010) Heavy metals toxicity in plants: An overview on the role of glutathione and phytochelatins in heavy metal stress tolerance of plants. South African Journal of Botany 76: 167-179.

Zhang F, Wan X, Zheng Y, Sun L, Chen Q, Guo Y, Zhu X \& Liu M (2014) Physiological and related anthocyanin biosynthesis genes responses induced by cadmium stress in a new colored-leaf plant 'Quanhong Poplar'. Agroforestry Systems 88: 343-355. 